九州大学学術情報リポジトリ

Kyushu University Institutional Repository

Effects of Rice Straw, Annual Ryegrass Straw and Klein Grass Hay on Disappearance Rates of Nutrients in the Rumen and $\mathrm{CH} 4$ Emission in Hanwoo Cows

Yang, Ka Young

Laboratory of Animal Welfare Management, College of Animal Life Sciences, Kangwon National University

Kim, Soo Young

Laboratory of Urban Planning, Department of Urban Planning, Graduate School of Urban Planning, Inha University

Kim, Young Sub

Laboratory of Animal Welfare Management, College of Animal Life Sciences, Kangwon National University

Ha, Jae Jung

Gyeongsangbuk-Do Livestock Reserch Institute

他

https://doi.org/10.5109/1526394

出版情報：九州大学大学院農学研究院紀要. 60 (2)，pp.349-355，2015-09-18. Faculty of Agriculture, Kyushu University

バージョン：

権利関係 : 


\title{
Effects of Rice Straw, Annual Ryegrass Straw and Klein Grass Hay on Disappearance Rates of Nutrients in the Rumen and $\mathrm{CH}_{4}$ Emission in Hanwoo Cows
}

\author{
Ka Young YANG ${ }^{1}$, Soo Young KIM ${ }^{2}$, Young Sub KIM${ }^{1}$, Jae Jung HA \\ Masataka SHIMOJO and Young Han SONG ${ }^{1 *}$
}

\author{
Laboratory of Regulation in Metabolism and Behavior, Division of Animal and Marine Bioresource Sciences, \\ Department of Bioresource Sciences, Faculty of Agriculture, \\ Kyushu University, Fukuoka 812-8581, Japan \\ (Received May 11, 2015 and accepted May 19, 2015)
}

\begin{abstract}
The objective of this study was to investigate the effects of rice straw, annual ryegrass straw, and Klein grass hay on ruminal disappearance characteristics and $\mathrm{CH}_{4}$ emission in Hanwoo cows. Two Hanwoo cows $(358 \pm 10.61 \mathrm{~kg})$ fistulated at the rumen were treated with two replications of each treatment during the 63-day experimental period. In accordance with TDN (total digestible nutrients) of the Korean Feeding Standard for Hanwoo (NISA, 2007), concentrates and forage (6:4 ratio) were provided twice a day, with a free access to mineral block and water. Using the in situ method with a nylon bag, disappearance rates in the rumen of $\mathrm{DM}, \mathrm{CP}, \mathrm{NDF}$, and $\mathrm{ADF}$ were measured. $\mathrm{CH}_{4}$ emissions were measured hourly using a hood-type chamber. Disappearance rates in the rumen of DM, CP, NDF, and ADF were higher in Klein grass hay, rice straw, and annual ryegrass straw, in that order, with significantly higher $(p<0.01)$ in Klein grass hay than in rice straw and annual ryegrass. The average hourly $\mathrm{CH}_{4}$ emissions were as follows; annual ryegrass straw $(169.89 \pm 6.94 \mathrm{mg} / \mathrm{hr})$, rice straw $(139.92 \pm 18.89 \mathrm{mg} / \mathrm{hr})$, and Klein grass hay $(128.20 \pm 4.91 \mathrm{mg} / \mathrm{hr})$, significantly higher $(\mathrm{p}<0.01)$ in annual ryegrass straw than in Klein grass hay. These results suggest that rice straw is a useful feed resource for ruminant production, which is mostly utilized as a domestic feed. However, imported roughage such as annual ryegrass straw showed lower disappearance and higher $\mathrm{CH}_{4}$ emission than rice straw.
\end{abstract}

Key words: Annual ryegrass straw, $\mathrm{CH}_{4}$, Hanwoo cow, Klein grass hay, rice straw

\section{INTRODUCTION}

The self-sufficiency rate of the forages in the recent years in Korea is just at around 84\% (Woo, 2010), with grasses and forage crops occupying around $38 \%$ and rice straw around 46\% (Han et al., 2009). Therefore, around $16 \%$ of feeds are pasture plants that are used for livestock (Woo, 2010). However, it was reported that the content of crude protein in the imported forages domestically used is lower than that proposed in the standard tables of feed composition in Korea published by the National Institute of Animal Science (NIAS, 2007) (Lee and Lee, 2000; Lee et al., 2001). Further it is expected that there could be imported forages that have more or less inferior quality than rice straw that uses most of the domestic lands. It is necessary to evaluate the feed's value for the imported forages. However, it is difficult to evaluate the nutrient composition at fields (Kim et al., 2005).

Forage is essential for ruminants. Ruminants digest the ingested feeds by the microorganism in the rumen, using them as energy. The gases that are produced while ruminants digest feeds are known to be $\mathrm{CO}_{2}, \mathrm{CH}_{4}, \mathrm{~N}_{2} \mathrm{O}$, and $\mathrm{O}_{2} \cdot \mathrm{CH}_{4}$ is produced by the action of methanogen in

\footnotetext{
1 Laboratory of Animal Welfare Management, College of Animal Life Sciences, Kangwon National University, the Republic of Korea

2 Laboratory of Urban Planning, Department of Urban Planning, Graduate School of Urban Planning, Inha University, the Republic of Korea

${ }^{3}$ Gyeongsangbuk-Do Livestock Reserch Institute, Muk-ri 275, Yeongju Gyeongasangbuk-Do 750-871, the Republic of Korea

* Corresponding author (E-mail: yhsong@kangwon.ac.kr)
}

the rumen and gives rise to around 2-12\% energy loss (Kim, 1999). Since discharged $\mathrm{CH}_{4}$ causes a strong greenhouse effect, there have been many researches such as effects of methane inhibitors on ruminal fermentation characteristics and methane production (Oh et al., 1998), effects of halogenated compounds on in vitro fermentation characteristics in the rumen and methane emissions (Czerkawski et al., 1966), effect of monensin on methane and heat productions of steers fed lucerne hay (O'kelly and Spiers, 1992), evaluation on the greenhouse gas emission according to the intake levels of total mixed rations of Hanwoo cow (Kim et al., 2011), and effect of green tea, garlic, and may flower powder supplementation on greenhouse gas emission in Hanwoo cow (Kim, 2012) to reduce this greenhouse effect. These various preceding researches were performed with the major target to reduce $\mathrm{CH}_{4}$ production by feeding animals with additives in the feeds. However, researches about $\mathrm{CH}_{4}$ produced from Hanwoo through different types of forages are lacking.

This study was conducted to investigate the effects of rice straw used most in Korea, annual ryegrass (Italian ryegrass) and Klein grass hay among imported forages on the disappearance rate of nutrients in the rumen and $\mathrm{CH}_{4}$ production in Hanwoo cows.

\section{MATERIALS AND METHODS}

\section{Animals, experimental period, and experimental site \\ Two heads of Hanwoo cow (average body weight: $358 \pm 10.61 \mathrm{~kg}$ ) fitted with rumen cannula were used for}


the experiment. The experiment was performed in the Ruminants Laboratory of Kangwon National University from February 1 till April 14, 2012 for a period totaling 63 days. The preliminary experiment for 30 days was conducted to adapt the animals to the metabolism cage. This was followed by the in situ test, and the animals were fed rice straw, annual ryegrass straw and Klein grass hay in the main experiment with four replications.

\section{Feeds for experiment and growing management}

Dried rice straw, annual ryegrass straw (Italian ryegrass straw), and Klein grass hay were used as feeds for the animals. Restricted feeding was performed with concentrates and forage at the mixture ratio of 6:4 according to the total digestible nutrients (TDN) required for maintaining a mature cow as in the Korean feeding standard from the National Institute of Animal Science (NIAS, 2007) as shown in Table 1.

Feeds were given as a batch with $3 \mathrm{~kg}$ of concentrates and $1.6 \mathrm{~kg}$ of rice straw, or $2.8 \mathrm{~kg}$ of concentrates and $1.8 \mathrm{~kg}$ of annual ryegrass straw, or $2.8 \mathrm{~kg}$ of concentrates and $1.86 \mathrm{~kg}$ of Klein grass hay twice a day (at 08:30 and 17:30), while the animals had free access to water and mineral blocks. Feeds for the experiment were analyzed by the methods of AOAC (1995), while NDF and ADF were analyzed by the methods of Goering and Van Soest (1970). The general compositions of the feeds are shown

Table 1. Maintenance nutritional requirement of Hanwoo cows

\begin{tabular}{|c|c|c|c|c|}
\hline \multirow{2}{*}{ Item } & \multicolumn{2}{|c|}{ TDN(kg) } & \multirow{2}{*}{$\begin{array}{l}\text { DMI } \\
(\mathrm{kg})\end{array}$} & \multirow{2}{*}{$\begin{array}{l}\text { CP } \\
(\%)\end{array}$} \\
\hline & standard & feeding & & \\
\hline Rice straw & \multirow{2}{*}{2.78} & 0.70 & 1.6 & \multirow{2}{*}{16.2} \\
\hline Concentrates & & 2.11 & 3 & \\
\hline Annual ryegrass straw & \multirow{2}{*}{2.78} & 0.84 & 1.8 & \multirow{2}{*}{13.3} \\
\hline Concentrates & & 1.97 & 2.8 & \\
\hline Klein grass hay & \multirow{2}{*}{2.78} & 0.84 & 1.86 & \multirow{2}{*}{20} \\
\hline Concentrates & & 1.97 & 2.8 & \\
\hline
\end{tabular}

Table 2. Chemical composition of experimental diets (DM basis)

\begin{tabular}{ccccc}
\hline $\begin{array}{c}\text { Chemical } \\
\text { composition } \\
(\%)\end{array}$ & Concentrates & $\begin{array}{c}\text { Rice } \\
\text { straw }\end{array}$ & $\begin{array}{c}\text { Annual } \\
\text { ryegrass } \\
\text { straw }\end{array}$ & $\begin{array}{c}\text { Klein } \\
\text { grass } \\
\text { hay }\end{array}$ \\
\hline $\begin{array}{c}\text { Moisture } \\
\text { Crude protein }\end{array}$ & 10.94 & 7.37 & 7.65 & 6.37 \\
Crude fiber & 3.88 & 27.98 & 35.81 & 31.94 \\
Ether extract & 3.26 & 1.84 & 1.06 & 0.85 \\
Crude ash & 6.39 & 8.36 & 4.36 & 7.83 \\
NDF & 23.83 & 66.06 & 68.66 & 67.41 \\
ADF & 10.51 & 41.33 & 47.77 & 43.00 \\
NFE $^{1)}$ & 49.56 & 50.14 & 49.31 & 44.50 \\
TDN $^{2)}$ & 70.26 & 26.84 & 25.90 & 41.69 \\
\hline
\end{tabular}

\footnotetext{
1) Nitrogen-free extract.

${ }^{2)}$ Calculated values (Weiss et al., 1992).
}

in Table 2.

General composition analysis results showed that the CP contents from annual ryegrass straw and Klein grass hay were in the range of 1.81-8.51\% which was of similar level with the preceding report that the CP contents from imported hay was mostly lower than $7-10 \%$ (Lee et al., 2001; Lee and Lee, 2000). Rice straw that is produced and used most in Korea, annual ryegrass straw with lower CP and TDN as compared with those in the rice straw, and Klein grass hay having higher CP and TDN among the imported forages were chosen as test feeds by referring to the general composition analysis table.

\section{Analyses}

\section{In situ Measurements}

In situ digestion experiment with the ruminants was carried out using a nylon bag having a porosity of $50 \mu \mathrm{m}$ (Ankom technology) according to the methods of Ørskov and McDonald (1979). Ten grams of powder-form concentrates were put into the nylon bag, while annual ryegrass straw and Klein grass hay were cut into around $3-5 \mathrm{~cm}$ lengths by scissors and five grams of these cut grasses were put into the nylon bag. Two replications were made for the experiment with concentrates, rice straw, annual ryegrass straw, and Klein grass hay. The nylon bags with feeds were put through the cannula into the rumen. This was followed by collecting nylon bags at $0,6,12,24,48$, and 72 hours after feeding to investigate the disappearance rate of nutrients in the rumen. Collected nylon bags were washed with a running tap water till clear water was running and then dried in the forced convective drying oven at $65^{\circ} \mathrm{C}$ for 72 hours. After that, the residue was collected and weighed to calculate the $\mathrm{DM}, \mathrm{CP}, \mathrm{NDF}$, and $\mathrm{ADF}$ disappearance rates (\%) using the equation below.

1) DM disappearance rate (\%)

$$
=\frac{\text { Sample DM }(\mathrm{g})-\text { Residue DM }(\mathrm{g})}{\text { Sample DM }(\mathrm{g})} \times 100
$$

2) CP disappearance rate (\%)

$$
=\frac{\text { Sample CP }(\mathrm{g})-\text { Residue CP }(\mathrm{g})}{\text { Sample CP }(\mathrm{g})} \times 100
$$

3) NDF disappearance rate (\%)

$$
=\frac{\text { Sample NDF }(\mathrm{g})-\text { Residue NDF }(\mathrm{g})}{\text { Sample NDF }(\mathrm{g})} \times 100
$$

4) $\mathrm{ADF}$ disappearance rate (\%)

$$
=\frac{\text { Sample ADF }(\mathrm{g})-\text { Residue ADF }(\mathrm{g})}{\text { Sample ADF }(\mathrm{g})} \times 100
$$

\section{$\mathrm{CH}_{4}$ Measurement}

$\mathrm{CH}_{4}$ production was measured with a hood-type chamber. The metabolism cage was set to $230 \mathrm{~cm}$ (width) $\times 205 \mathrm{~cm}$ (height) $\times 140 \mathrm{~cm}$ (length), which was then occupied by one cow with its head placed inside the chamber sealed with a transparent acryl having a size of $100 \mathrm{~cm}$ (width) $\times 139 \mathrm{~cm}$ (height) $\times 92 \mathrm{~cm}$ (length) 

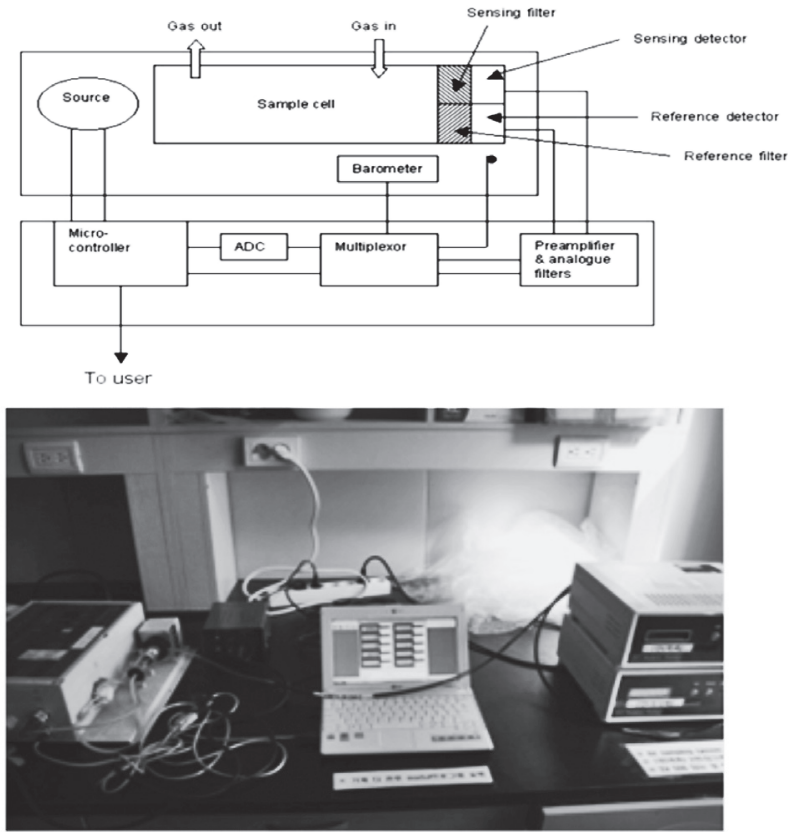

Fig. 1. Apparatus for measuring greenhouse gases and gas monitoring system (Mamos-300, Australia).

With a transparent acryl plate, all the activities and states such as the conditions and feed intake of the animals could be observed during greenhouse gas measurements. The animals have gone through an adaptation period of two weeks and another two weeks of preliminary experiment inside a hood-type chamber before switching to the main experiment, with an adaptation period of four days for the rice straw, annual ryegrass straw, and Klein grass hay, respectively. The measurement was carried out for two days. Greenhouse gas was measured using a multiple gases detector (mamos-300, Australia) with the help of a non-dispersive infrared absorption (NDIR) sensor as shown in Figure 1.

\section{Statistical Analyses}

All the results obtained during the experiment were analyzed using the General Liner Model (GLM) from Statistical Analysis System (SAS, ver. 9.2). Significance test was carried out for the treatment interval using the Duncan's multiple range tests.

$Y_{i j}$ : The measurement value for the $i$ th forage and the $j$ th animal

$\mu$ : The average of the total

$G i$ : The effect of the $i$ th forages $(i=1,2$, and 3$)$

eij: The uncertainty error

\section{RESULTS AND DISCUSSION}

Comparison of in situ disappearance rates for rice straw, annual ryegrass straw, and Klein grass hay

\section{DM disappearance rate}

The DM disappearance rates measured in the rumen of the animals are presented in Table 3 and Figure 2.

DM disappearance rates in the rumen of rice straw, annual ryegrass straw, and Klein grass hay increased as the fermentation progressed. The DM disappearance of
Klein grass hay was significantly higher $(p<0.01)$ compared with rice straw and annual ryegrass straw. This higher disappearance of DM might be due to the increased number of protein degrading microorganisms in the rumen, because protein contents in the gramineous forages are high (Choi, 2007). Though there were no significant differences $(p>0.05)$, the rice straw tended to show a slightly higher DM disappearance rate than the annual ryegrass straw.

The DM disappearance rate of the forages in the rumen at the interval of 24 hours was found highest in the initial 24 hours, followed by the third 24 hours (48 72 hours). When compared with the results in the preceding studies (Ørskov and McDonald, 1979), the DM disappearance rate of the forages, especially that of the rice straw was found to be low. It might be because the forage was crushed in a Wiley mill with a screen having mesh at around $1-2 \mathrm{~mm}$, cutting into around $3-5 \mathrm{~cm}$ lengths instead of putting the crushed forages into the nylon bag ultimately reduced the disappearance of DM and the activation of microorganisms. Further, since the rice straw was cut instead of being crushed in the Wiley mill, the amount of DM escaping through the pore of the nylon bag might be relatively low.

Table 3. Effects of experimental diets on in situ dry matter disappearance in Hanwoo cows

\begin{tabular}{cccc}
\hline & \multicolumn{3}{c}{ Treatment } \\
\cline { 2 - 4 } Time (hr) & Rice straw & $\begin{array}{c}\text { Annual ryegrass } \\
\text { straw }\end{array}$ & Klein grass hay \\
\hline $0^{1)}$ & $8.16 \pm 1.21^{2 \mathrm{~b}}$ & $6.96 \pm 0.96^{\mathrm{b}}$ & $15.11 \pm 1.63^{\mathrm{a}}$ \\
6 & $12.28 \pm 0.71^{\mathrm{b}}$ & $9.55 \pm 0.35^{\mathrm{b}}$ & $21.88 \pm 0.57^{\mathrm{a}}$ \\
12 & $15.79 \pm 1.39^{\mathrm{b}}$ & $10.86 \pm 0.91^{\mathrm{b}}$ & $29.43 \pm 4.62^{\mathrm{a}}$ \\
24 & $18.17 \pm 2.13^{\mathrm{b}}$ & $14.17 \pm 1.51^{\mathrm{b}}$ & $36.06 \pm 0.98^{\mathrm{a}}$ \\
48 & $21.12 \pm 0.40^{\mathrm{b}}$ & $17.65 \pm 0.13^{\mathrm{b}}$ & $38.50 \pm 0.89^{\mathrm{a}}$ \\
72 & $31.63 \pm 5.03^{\mathrm{b}}$ & $29.96 \pm 7.16^{\mathrm{b}}$ & $48.43 \pm 5.89^{\mathrm{a}}$ \\
\hline
\end{tabular}

1) Values at 0 hr show the amount that passed through the pores of the nylon bag by only washing with running tap water.

2) Values are mean \pm standard deviation.

${ }^{a, b}$ Means with different letters in the same row are significantly different $(p<0.01)$.

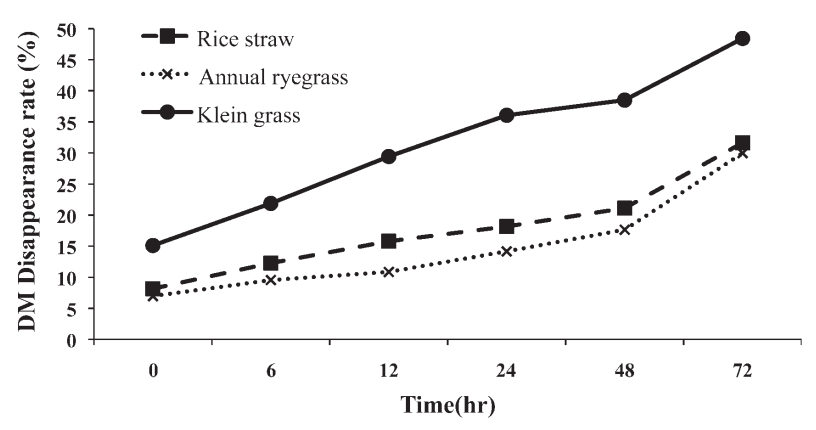

Fig. 2. Effects of experimental diets on in situ DM disappearance in Hanwoo cows. 


\section{CP Disappearance Rate}

The CP disappearance rates in the rumen according to the fermentation duration are shown in Table 4 and Figure 3.

Table 4. Effects of experimental diets on in situ crude protein disappearance in Hanwoo cows

\begin{tabular}{cccc}
\hline & \multicolumn{3}{c}{ Treatment } \\
\cline { 2 - 4 } Time(hr) & Rice straw & $\begin{array}{c}\text { Annual ryegrass } \\
\text { straw }\end{array}$ & Klein grass hay \\
\hline $0^{1)}$ & $12.80 \pm 1.15^{2) \mathrm{b}}$ & $10.97 \pm 0.92^{\mathrm{b}}$ & $17.04 \pm 1.59^{\mathrm{a}}$ \\
6 & $16.89 \pm 0.67^{\mathrm{b}}$ & $12.02 \pm 0.34^{\mathrm{b}}$ & $21.50 \pm 0.57^{\mathrm{a}}$ \\
12 & $25.82 \pm 1.64^{\mathrm{b}}$ & $23.79 \pm 0.97^{\mathrm{b}}$ & $33.68 \pm 6.06^{\mathrm{a}}$ \\
24 & $26.88 \pm 2.53^{\mathrm{b}}$ & $25.00 \pm 1.77^{\mathrm{b}}$ & $39.47 \pm 1.35^{\mathrm{a}}$ \\
48 & $33.60 \pm 0.46^{\mathrm{b}}$ & $30.08 \pm 2.50^{\mathrm{b}}$ & $49.29 \pm 1.34^{\mathrm{a}}$ \\
72 & $41.47 \pm 6.22^{\mathrm{b}}$ & $37.55 \pm 10.40^{\mathrm{b}}$ & $54.61 \pm 10.60^{\mathrm{a}}$
\end{tabular}

1) Values at $0 \mathrm{hr}$ show the amount that passed through the pores of the nylon bag by only washing with running tap water.

2) Values are mean \pm standard deviation.

${ }^{a, b}$ Means with different letters in the same row are significantly different $(\mathrm{p}<0.01)$.

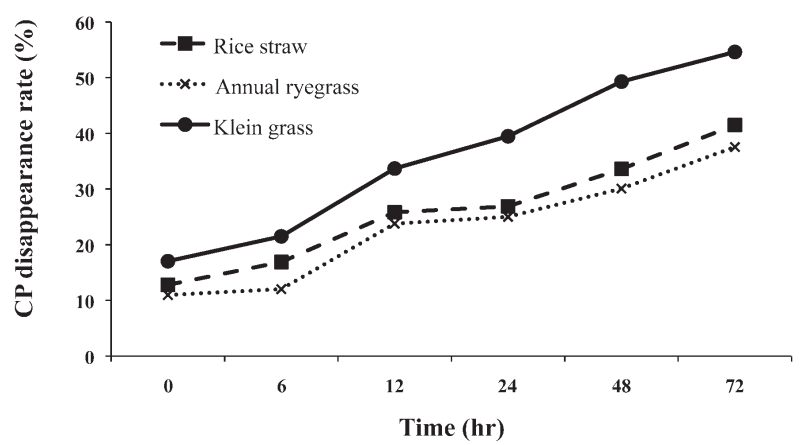

Fig. 3. Effects of experimental diets on in situ CP disappearance in Hanwoo cows.

The CP disappearance rate of the Klein grass hay was significantly higher $(p<0.01)$ than that of the rice straw and the annual ryegrass straw. This result was different from the results reported by Han et al. (2009) that CP was mostly very low in the straws than in the hays. However, it implies that CP contents can be differently included in the forages according to the collection location of the herbages (Wood and Tanner, 1985), species seed combination (Peel and Green, 1984), preparation method of the forages, harvest stage, and distribution states (Lee et al., 2001). Though there was no significant difference $(p>0.05)$ in the CP contents between the rice straw and the annual ryegrass, the $\mathrm{CP}$ disappearance rate of rice straw tended to be slightly higher than the annual ryegrass straw. CP disappearance rates of rice straw, annual ryegrass straw, and Klein grass hay gradually increased as the fermentation time progressed in the rumen. Further, CP disappearance rates of rice straw, annual ryegrass straw, and Klein grass hay showed large increases from 6 to 12 hours of the fermentation in the rumen. This result was different from that by Seok
(2009). Yet, this might be due to the effect of the washing method (Kempton, 1980) and types of the sample. The highest rate of CP disappearance was found in the Klein grass hay among the forages tested, whilst the lowest CP disappearance was found from the annual ryegrass straw. Klein grass hay showed a higher CP disappearance rate from the beginning of the experiment, which might be due to its high CP contents that could be dissolved independently from the disappearance action by the microorganism in the rumen.

\section{Disappearance Rates of NDF and ADF}

Tables 5 and 6 show the disappearance rates of NDF and $\mathrm{ADF}$ according to the fermentation time in the rumen, respectively. Figures 4 and 5 present the changes in the disappearance rates of NDF and ADF during each measurement time.

NDF disappearance rate was significantly higher $(p<0.01)$ in Klein grass hay in the rumen. Further, there was no significant difference ( $p>0.05)$ in the NDF disappearance rate between rice straw and annual ryegrass

Table 5. Effects of experimental diets on in situ NDF disappearance in Hanwoo cows

\begin{tabular}{cccc}
\hline & \multicolumn{3}{c}{ Treatment } \\
\cline { 2 - 4 } Time(hr) & Rice straw & $\begin{array}{c}\text { Annual ryegrass } \\
\text { straw }\end{array}$ & Klein grass hay \\
\hline $0^{1)}$ & $6.13 \pm 1.24^{2) \mathrm{b}}$ & $1.09 \pm 1.02^{\mathrm{b}}$ & $4.78 \pm 1.83^{\mathrm{a}}$ \\
6 & $10.72 \pm 0.72^{\mathrm{b}}$ & $4.40 \pm 0.97^{\mathrm{b}}$ & $16.93 \pm 0.60^{\mathrm{a}}$ \\
12 & $12.72 \pm 1.45^{\mathrm{b}}$ & $4.57 \pm 0.37^{\mathrm{b}}$ & $21.27 \pm 5.15^{\mathrm{a}}$ \\
24 & $17.74 \pm 2.14^{\mathrm{b}}$ & $10.29 \pm 1.58^{\mathrm{b}}$ & $34.82 \pm 1.00^{\mathrm{a}}$ \\
48 & $23.00 \pm 0.39^{\mathrm{b}}$ & $20.26 \pm 0.13^{\mathrm{b}}$ & $41.89 \pm 0.84^{\mathrm{a}}$ \\
72 & $37.22 \pm 4.62^{\mathrm{b}}$ & $36.23 \pm 6.52^{\mathrm{b}}$ & $53.17 \pm 5.35^{\mathrm{a}}$ \\
\hline
\end{tabular}

1) Values at 0 hr show the amount that passed through the pores of the nylon bag by only washing with running tap water.

Values are mean \pm standard deviation.

${ }^{\mathrm{a}, \mathrm{b}}$ Means with different letters in the same row are significantly different $(\mathrm{p}<0.01)$

Table 6. Effects of experimental diets on in situ ADF disappearance in Hanwoo cows

\begin{tabular}{cccc}
\hline & \multicolumn{3}{c}{ Treatment } \\
\cline { 2 - 4 } Time(hr) & Rice straw & $\begin{array}{c}\text { Annual ryegrass } \\
\text { straw }\end{array}$ & Klein grass hay \\
\hline $0^{1)}$ & $3.51 \pm 1.27^{2) \mathrm{b}}$ & $1.18 \pm 1.02 \mathrm{~b}$ & $2.68 \pm 1.87^{\mathrm{a}}$ \\
6 & $6.11 \pm 0.76^{\mathrm{b}}$ & $5.97 \pm 0.37^{\mathrm{b}}$ & $13.27 \pm 0.63^{\mathrm{a}}$ \\
12 & $11.81 \pm 1.46^{\mathrm{b}}$ & $7.19 \pm 0.94^{\mathrm{b}}$ & $23.48 \pm 5.01^{\mathrm{a}}$ \\
24 & $14.45 \pm 2.22^{\mathrm{b}}$ & $13.10 \pm 1.53^{\mathrm{b}}$ & $30.12 \pm 1.07^{\mathrm{a}}$ \\
48 & $17.80 \pm 0.41^{\mathrm{b}}$ & $20.24 \pm 0.13^{\mathrm{b}}$ & $38.57 \pm 0.89^{\mathrm{a}}$ \\
72 & $32.82 \pm 4.95^{\mathrm{b}}$ & $34.44 \pm 6.71^{\mathrm{b}}$ & $52.42 \pm 5.43^{\mathrm{a}}$
\end{tabular}

1) Values at $0 \mathrm{hr}$ show the amount that passed through the pores of the nylon bag by only washing with running tap water.

2) Values are mean \pm standard deviation.

${ }^{a, b}$ Means with different letters in the same row are significantly different $(p<0.01)$ 


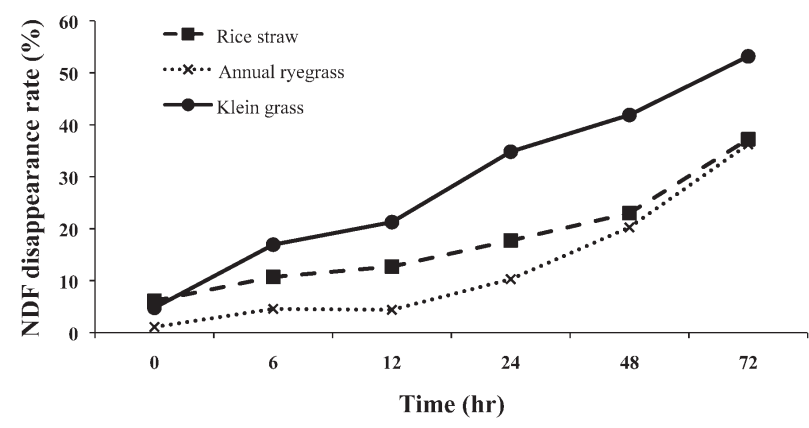

Fig. 4. Effects of experimental diets on in situ NDF disappearance in Hanwoo cows.

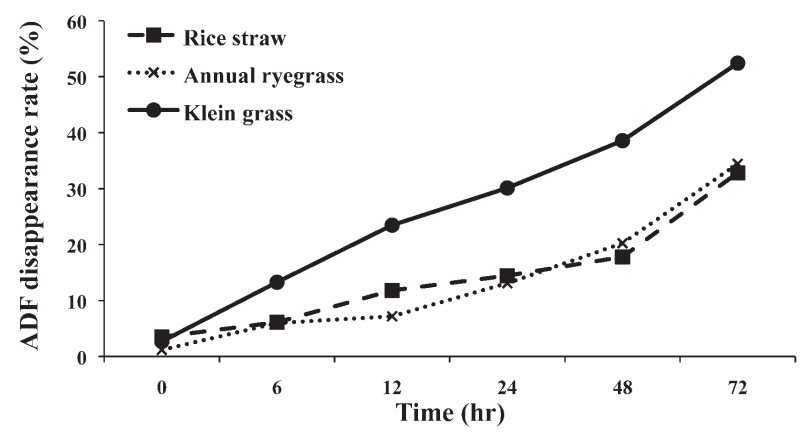

Fig. 5. Effects of experimental diets on in situ ADF disappearance in Hanwoo cows.

straw. However, a little higher NDF disappearance rate tended to be observed in the rice straw in all the time intervals than in the annual ryegrass straw. The NDF disappearance rate occurring at zero hour was a disappearing from the pore of the nylon bag. This result was consistent with the preceding study (Kim et al., 2005) that the NDF content increased as the CP and the components inside the cell were decreased.

The NDF disappearance rates of the rice straw, annual ryegrass straw, and Klein grass hay gradually increased as the fermentation progressed in the rumen. Moreover, the NDF disappearance rate of Klein grass hay showed a higher increase than that of rice straw and annual ryegrass straw. Similar NDF disappearance rates were observed between annual ryegrass and rice straw.

The ADF disappearance was significantly higher $(p<0.01)$ in Klein grass hay than in the rice straw and the annual ryegrass straw. There was no significant difference $(p>0.05)$ in the ADF disappearance rate between the rice straw and annual ryegrass straw. The ADF disappearance rate occurring at zero hour was the disappearance from the pores of the nylon bag.

A large amount of ADF disappeared quickly from Klein grass hay compared with rice straw and annual ryegrass straw, both straws did not show any difference in $\mathrm{ADF}$ disappearance rate. A particular thing observed was that the disappeared ADF of annual ryegrass straw increased from 12 hours of the fermentation in the rumen, and after 24 hours the ADF disappearance tended to be slightly higher in annual ryegrass straw than in rice straw.
The disappearance rates of $\mathrm{DM}, \mathrm{CP}, \mathrm{NDF}$, and $\mathrm{ADF}$ overall showed the highest values in the Klein grass hay during all the observation times. Meanwhile, although the disappearance rates of the above components in the annual ryegrass were not significantly higher $(p>0.05)$ than those in the rice straw, decreasing trends of $\mathrm{DM}, \mathrm{CP}$, $\mathrm{NDF}$, and $\mathrm{ADF}$ were observed. It was reported that the digestion rate of pasture plants was higher than that of the straws (Ndlovu Buchanan-Smith, 1985; Poore et al., 1991). The results of this study, in which the disappearance rates of $\mathrm{DM}, \mathrm{CP}, \mathrm{NDF}$, and $\mathrm{ADF}$ of the good quality pasture plants Klein grass hay were significantly higher $(p<0.01)$ than those of rice straw and annual ryegrass straw, are in conformity with the preceding researches.

\section{$\mathrm{CH}_{4}$ production by animals fed rice straw, annual ryegrass straw, or Klein grass hay}

$\mathrm{CH}_{4}$ production

The average $\mathrm{CH}_{4}$ productions per day by feeding rice straw, annual ryegrass, or Klein grass hay are presented in Table 7.

Table 7. Effects of experimental diets on $\mathrm{CH}_{4}$ emission in Hanwoo cows

\begin{tabular}{|c|c|c|c|}
\hline \multirow[b]{2}{*}{ Item } & \multicolumn{3}{|c|}{ Treatment } \\
\hline & Rice straw & $\begin{array}{c}\text { Annual } \\
\text { ryegrass straw }\end{array}$ & $\begin{array}{c}\text { Klein grass } \\
\text { hay }\end{array}$ \\
\hline $\mathrm{CH}_{4}$ (mg/hr/day) & $139.92 \pm 18.89^{1 \mathrm{ab}}$ & $169.89 \pm 6.94^{\mathrm{a}}$ & $128.20 \pm 4.91^{\mathrm{b}}$ \\
\hline
\end{tabular}

Average $\mathrm{CH}_{4}$ production per hour was 139.92士 $18.89 \mathrm{mg}$ in rice straw, $169.89 \pm 6.94 \mathrm{mg}$ in annual ryegrass straw, and $128.20 \pm 4.91 \mathrm{mg}$ in Klein grass hay, respectively. The $\mathrm{CH}_{4}$ production was significantly higher $(\mathrm{p}<$ 0.01 ) in annual ryegrass straw than in Klein grass hay. The least $\mathrm{CH}_{4}$ production was found in Klein grass hay with the highest contents of CP. Getachew et al. (1998) reported the relationship between $\mathrm{CP}$ content in the feed and $\mathrm{CH}_{4}$ production, where $\mathrm{NH}_{4}{ }^{+}$produced from $\mathrm{CP}$ degradation was bonded with $\mathrm{CO}_{2}$ (a substrate for $\mathrm{CH}_{4}$ production) and the reduced production of $\mathrm{NH}_{4}^{+}$resulted in the reduced $\mathrm{CH}_{4}$ production. Terefore, we need additional researches about the $\mathrm{CH}_{4}$ production in Klein grass.

\section{$\mathrm{CH}_{4}$ production pattern}

The $\mathrm{CH}_{4}$ production during 24 hours by feeding rice straw, annual ryegrass straw, or Klein grass hay is shown in Figure 6. Though the $\mathrm{CH}_{4}$ production was greatly different according to the types of the forage ingested, the $\mathrm{CH}_{4}$ production patterns were generally similar in rice straw, annual ryegrass straw, and Klein grass hay.

The $\mathrm{CH}_{4}$ production showed rapid increases in one to two hours after feeding rice straw, annual ryegrass straw, or Klein grass hay. This agrees with the result by Song (2008) who reported that the highest $\mathrm{CH}_{4}$ level was due to the responsive burp by the animal, fitted with the high 


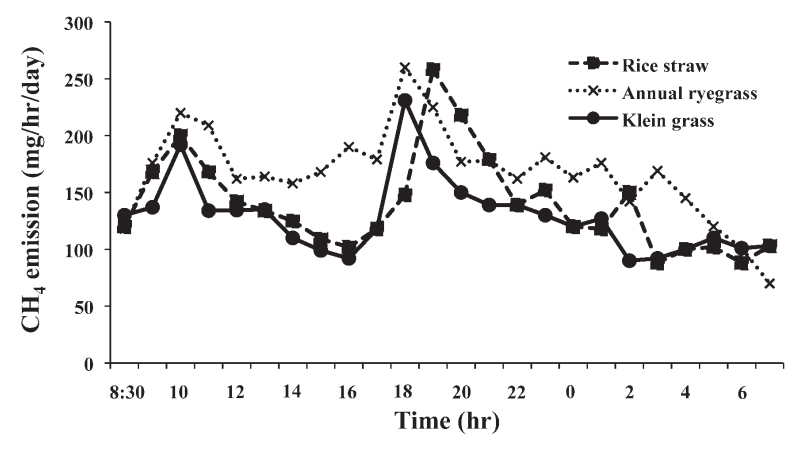

Fig. 6. Effects of experimental diets on $\mathrm{CH}_{4}$ emission in Hanwoo cows.

level of gas pressure inside the rumen, that actively occurred in one to two hours after feeding. When day and night were divided at hour 20, the $\mathrm{CH}_{4}$ production was generally higher during day than during night. This result matches with the report by Jeon (1988) that cows ruminate more during day than during night.

Correlation between the nutrient disappearance rate in the rumen and $\mathrm{CH}_{4}$ production by feeding rice straw, annual ryegrass straw, or Klein grass hay

Figure 7 shows the correlation between the nutrient disappearance rate in the rumen and $\mathrm{CH}_{4}$ production by feeding rice straw, annual ryegrass straw, or Klein grass hay to the animals. The correlation between the disappearance rates of $\mathrm{DM}, \mathrm{CP}, \mathrm{NDF}$, and $\mathrm{ADF}$ and $\mathrm{CH} 4$ production investigated using in situ method tends to display a negative (-) relationship for all the feeds types. Klein grass hay with a significantly higher $(p<0.01)$ disappearance rate in the rumen showed the significantly lower $(p<0.01) \mathrm{CH}_{4}$ production. This result was consistent with the report by Johnson and Johnson (1995) that when the feed was given to the livestock at an energy maintaining level, the $\mathrm{CH}_{4}$ production decreases per feed intake as the digestion rate increases.

\section{CONCLUSIONS}

As a conclusion, it would be beneficial to use pasture plants having higher CP and TDN, instead of straws like rice straws being used most in Korea that produce a high amount of $\mathrm{CH}_{4}$. Imported forage annual ryegrass straws might have lower CP and TDN contents compared with those in Italian ryegrass and crop barley that are produced in Korea. Further, it would give an adverse effect on the ruminal disappearances and $\mathrm{CH}_{4}$ production. Therefore, we would need additional researches about the effects of forage feeding on the nutrient disappearance rates in the rumen and $\mathrm{CH}_{4}$ production among Hanwoo species in the future.
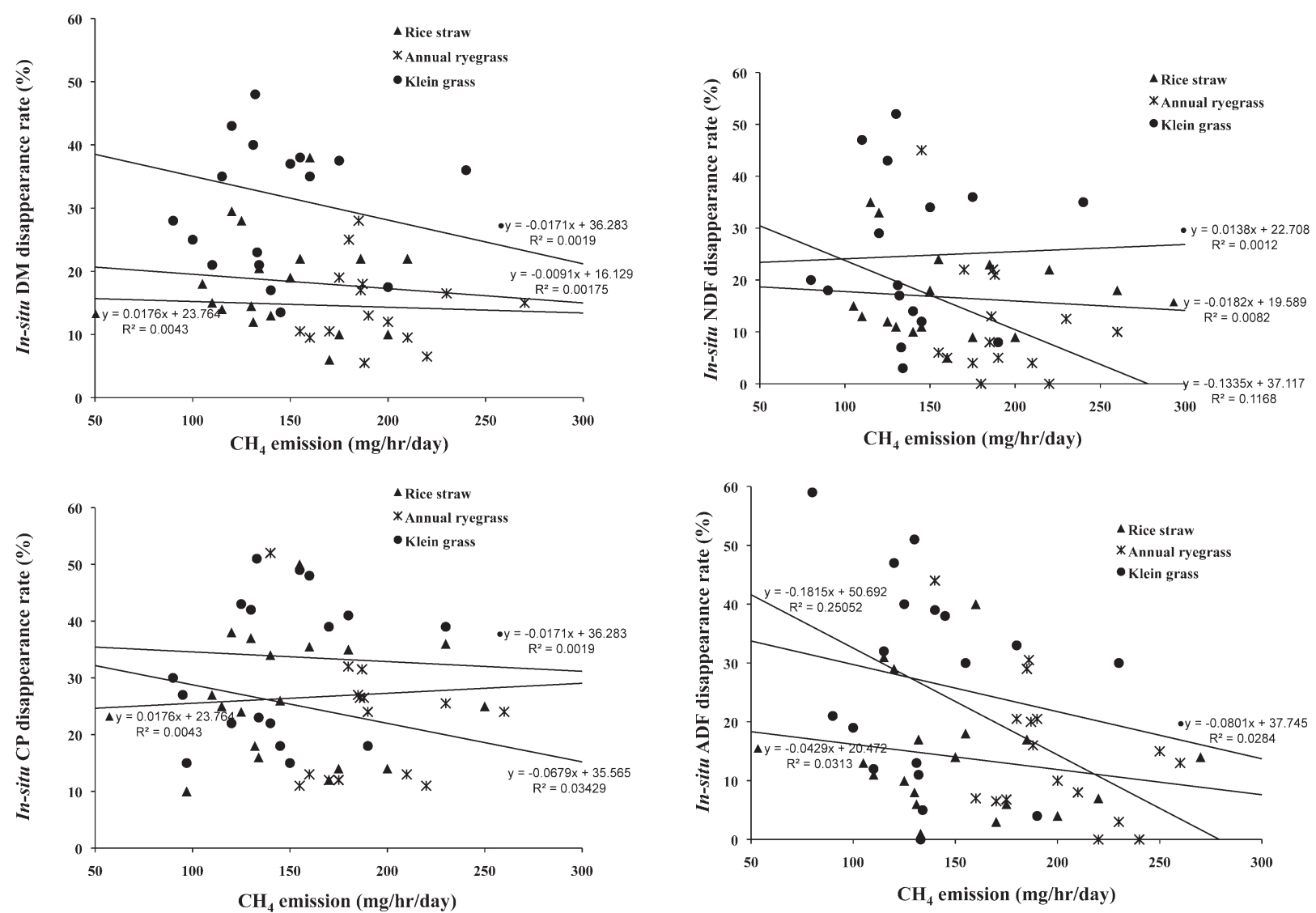

Fig. 7. Relation between in situ disappearance rates of nutrients and $\mathrm{CH}_{4}$ emission of experimental diets. 


\section{ACKNOWLEDGEMENTS}

The funding provided by Rural Development Administration, Korea under the grant number PJ00937201 to acknowledged. In addition, this study was supported by Institute of Animal Resources Kangwon National University (No. 120131267).

\section{REFERENCES}

AOAC. 1995 Official methods of analysis. 15th ed. Association of official agricultural chemists. Gaithersberg, MD, USA.

Choi, J. K. 2007 Effects of alcohol-fermented feedstuffs on fermentable characteristics of rumen and lactational response in Holstein cows. Doctoral's thesis. Kangwon National University, Chun-cheon.

Czerkawski. J. W., K. L. Blaxter and F. W. Wainman 1966 The metabolism of oleic, linoleic, and linolenic acids by sheep with reference to there effects on methane production. Br. J. Nutr., 20(2): 349-362

Getachew, G., M. Blummel, H. P. S. Makkarn and K. Becker 1998 In vitro gas measuring techniques for assessment of nutritional quality of feeds : a review. Anim. Feed. Sci. Technol, 72: 261281

Goering, H. K. and P. J. Van Soest 1970 Forage fiber analysis. Agriculture Handbook, No. 379: 1-24

Han, S. C., I. D. Lee and H. S. Lee 2009 Studies on the quality and palatability of imported hay and straw. J. Kor. Grassl. Forage Sci., 29(1): 73-82

Jeon, B. T. 1988 Variability of the rumination-behaviour in steers fed a constant amount of hay. J. Kor. Grassl. Forage Sci., 8(2): 68-76

Johnson, K. A. and D. E. Johnson. 1995 Methane emissions from cattle. J. Anim. Sci., 73: 2483-2492

Kempton, T. J. 1980 The use of nylon bags to characterize the potential degradability of feeds for ruminants. Trop. Anim. Prod., 5(3): 195-213

Kim, B. K. 1999 Study on the prediction of methane production from feed ingredients in the rumen. Master's thesis. Kunkuk University, Seoul.

Kim, D. R., J. J. Ha, J. T. Kim and Y. H. Song 2011 Animal environment : evaluation on the greenhouse gas emission according to the intake levels of total mixed rations of Hanwoo cow. $J$. Anim. Sci. Technol., 53(5): 475-480

Kim, D. R. 2012 Effect of green tea, garlic and may flower powder supplementation on greenhouse gas emission in Hanwoo cow. Master's thesis. Kangwon National University, Chun-cheon.

Kim, M. H., I. J. Seo, J. S. Kim and S. L. Lee 2005 Correlation between nutrient components of grass roughages mainly used in Korea. J. Kor. Grassl. Forage Sci., 25(3): 169-176

Lee, H. S. and I. D. Lee 2000 A comparative study of nutritive value of imported roughages. J. Kor. Grassl. Forage Sci. 20(4): 303-308

Lee, H. S., I. D. Lee, D. S. Park, Y. J. Park, S. K. Kim and J. S. Keum 2001 A study on the nutritive value of distributed roughage in domestic market. J. Kor. Grassl. Forage Sci., 21(3): 109114

Ndlovu, L. R. and J. G. Buchanan-Smith 1985 Utilization of poor quality roughages by sheep: effects of alfalfa supplementation on ruminal parameters, fiber digestion and rate of passage from the rumen. Can. J. Anim. Sci., 65(3): 693-703

NIAS (National Institute of Animal Science) 2007 Korean feeding standard for Hanwoo. pp. 26-27

Oh, Y. K., S. C. Lee, J. W. Kim, J. S. Eun, H. J. Sohn, J. G. Park and K. J. Kim 1998 Effects of methane inhibitors on ruminal fermentation characteristics and methane production. Kor. $J$. Anim. Nutr. Feed., 22(4): 247-258

O'Kelly, J. C. and W. G. Spiers 1992 Effect of monensin on methane and heat productions of steers fed lucerne hay either ad libitum or at the rate of $250 \mathrm{~g} /$ hour. Aust. J. Agric. Res., 43 : 1789-1793

Peel, S. and J. O. Green 1984 Sward composition and output on grassland farms. Grass and Forage Sci., 39: 107-110

Poore, M. H., J. A. Moore, R. S. Swingle, T. P. Eck, W. H. Brown 1991 Wheat straw or alfalfa hay in diets with $30 \%$ neutral detergent fiber for lactating Holstein cows. J. Dairy Sci. 74(9): 3152-3159

Ørskov, E. R. and I. McDonald 1979 The estimation of protein degradability in the rumen from incubation measurements weighted according to rate of passage. J. Agric. Sci. (Cambridge), 92(2): 499-503

SAS 2003 SAS software for PC. Release 9.2, SAS Institute Inc. Cary, NC, USA.

Seok, J. S. 2009 Evaluation on energy and nutrient utilization by sheep of spent mushroom substrates (SMS) and SMS-based fermented forage. Master's thesis. Kunkuk University, Seoul.

Song, Y. H. 2008 Feeding management technology for reducing greenhouse gas emissions. Greenhouse gas reduction plan for the livestock sector symposium. Inst. Anim. Res. Kangwon National Univ., pp. 96

Weiss, W. P., H. R. Conrad and N. R. St-Pierre 1992 A theoretically-based model for predicting total digestible nutrient values of forages and concentrates. Anim. Feed Sci. Technol., 39: $95-110$

Wood, J. M. and G. W. Tanner 1985 Browse quality response to forest fertilization and soils in florida. J. Range Manage., 38(5): 432-435

Woo, M. S. 2010 Promotion of production and use activation measures of roughage. Symposium J. Kor. Grassl. Forage Sci. Sang-ju. pp. 87-106 
